\title{
RE-INVENTING THE ROLE OF FEMALEULAMA IN THE INTELLECTUAL TRADITION OF ISLAM MALAY
}

\author{
Abdul Mujib \\ Institut Agama Islam Negeri (IAIN) Metro, Indonesia \\ E-mail:abdulmujib@metrouniv.ac.id
}

\begin{abstract}
Studies on the involvement of female ulama (Muslim clerics) in the Islamic intellectual tradition are still in quite small number, not only in Malay-Nusantara area, but also in other Muslim regions such as Arabia, West Asia, Africa, North Africa, subcontinent of India, and so forth. Even though the studies on woman and gender is recently getting their momentum, the focused attention is not referred to the socio-cultural history of female ulama. This paper is a library research in nature. It attempts to deeply present the role of Fathimahbinti Abdul WahabBugis in the intellectual tradition of Islam Malay. It is concluded that Fathima's role is very significantly considered in the intellectual tradition particularly in the field of figh(jurispundence).
\end{abstract}

Keywords:female ulama, Islam Malay, Fatimah binti Abdul WahabBugis.

\begin{abstract}
Abstrak
Studi tentang keterlibatan ulama perempuan dalam tradisi intelektual Islam masih sangat sedikit, tidak hanya di wilayah Melayu-Nusantara, tetapi juga di wilayah Muslim lainnya seperti Arab, Asia Barat, Afrika, Afrika Utara, anak benua India, dan sebagainya. Meskipun studi tentang perempuan dan gender baru-baru ini mendapatkan momentumnya, perhatian yang terfokus tidak mengacu pada sejarah sosial-budaya ulama perempuan. Makalah ini adalah penelitian perpustakaan di alam. Ini berusaha untuk secara mendalam mempresentasikan peran Fathimahbinti Abdul WahabBugis dalam tradisi intelektual Islam Melayu. Disimpulkan bahwa peran Fathima sangat signifikan dipertimbangkan dalam tradisi intelektual khususnya dalam bidang figh (jurispundence).

Kata kunci: ulama wanita, Islam Melayu, Fatimah binti Abdul WahabBugis.
\end{abstract}

\section{A. Introduction}

Female ulama?Are they in a big number? Do they have a significant role in the world? It is stated byAzyumardiAzra that the history of female ulama is still in the dark sources. There are not many things that can be known about this subject. There is a kind of common impression and cursoryobservation, which is of course in need of assessment, that femaleulamas do not have any appropriate places in historical sources and Islamic historiography. ${ }^{1}$

Azra's initial investigation on female ulama in the Middle East reveals that woman ulama does exist but very little written in the Islamic history sources, especially in the Middle East. There are a number of female ulama and women who plays a significant role in the field of Islamic insight and sciences such as hadith, figh, and tasawuf. Besides, there are also some women playing a crucial

\footnotetext{
1AzyumardiAzra, "Kajian Historis Biografi Sosial-Intelektual Ulama Perempuan", dalam AzyumardiAzra, Historiografi Islam Kontemporer: Wacana, Aktualitas, dan Aktor Sejarah, (Jakarta: Gramedia Pustaka Utama, 2002),p. 147; AzyumardiAzra, "Ulama Perempuan dan Wacana Islam", dalamAzyumardiAzra, Reposisi Hubungan Agama dan Negara: Merajut Kerukunan Antar umat, (Jakarta: Penerbit Buku Kompas, 2002), h. 82-83
} 
role in the establishment and development of Islamic educational institutions such as madrasah, pesantren, and so forth. ${ }^{2}$

Furthermore, in the Malay-Nusantara region, the involvement of female clerics in the transmission chains and Islamic scholarly traditions seems to still be an interesting puzzle to be traced back. Although it only occupies a marginal position, there is clearly a name of female scholars among the Malay-Nusantara clerics. One of them is Fatima binti Abdul WahabBugis. The presence of the grandson of Sheikh Muhammad Arsyad al-Banjari has helped develop the Islamic scholarship tradition in the Malay-Nusantara region, especially in Borneo earth, from the late 18th century until the mid-19th century. Fatima's mastery in the science of religion even becomes an important milestone for the emergence of scholars in the region of Borneo ${ }^{3}$. Unfortunately, Fatima's important intellectual contribution is often forgotten, like the "lost pearl" in her historical background.

\section{B. Biography and Intellectual Works of Fatima binti Abdul WahabBugis}

The name of Fatima binti Abdul WahabBugis may not be too well known among Malay-Nusantara scholars, but this female cleric is often mentioned as a writer of Malay Paracels, a yellow book with Arabic-Malay script (Jawi) which is widely studied in almost all Malay-Indonesian territory ${ }^{4}$. He was born in Martapura, South Kalimantan, from an educated family.

Fatima binti Abdul WahabBugis would have been lucky to be born and raised in an educated family. His grandfather, Sheikh Muhammad Arsyad alBanjari, is one of the famous scholars in the archipelago. Born in Martapura, Muhammad Arsyad first received religious education in his own village, from both parents and local teachers5. From his young age, he has shown his artistic talents and intellectual acumen in the eyes of his parents and the surrounding community. While traveling to the villages, the Sultan met with him and was attracted to his extraordinary talents, especially his ability in painting. Then Sultan asked his parents to bring Muhammad Arsyad to the palace. The request

${ }^{2}$ AzyumardiAzra, "Biografi Sosial-intelektual Ulama Perempuan: Pemberdayaan Historiografi", dalamJajat Burhanudin (ed.), Ulama Perempuan Indonesia,(Jakarta: Gramedia Pustaka Utama, 2002), p. xxii; Azyumardi Azra, "Kajian Historis Biografi",p. 147-148; Azyumardi Azra, "Ulama Perempuan",h. 82-96

${ }^{3}$ Ramli Nawawi (ed.), Sejarah Pendidikan Daerah Kalimantan Selatan, (Banjarmasin: Departemen Pendidikan dan Kebudayaan, 1992/1993), h. 18; Alfisyah, "Geneologi Gerakan Perempuan Banjar", Kandil, No. 11, Th. III, November-Januari, 2006, h. 6; Saifuddin, Norlaila, danHalimatusSakdiah, "Ulama Perempuan Banjar dalam Penulisan Kitab Kuning: Studi Historis dan Tekstual atas Kitab Parukunan Melayu", (Banjarmasin: Pusat Penelitian IAIN Antasari, 2008), h. 31.

4Zuhairiniet al., Sejarah Pendidikan Islam, (Jakarta: Bumi Aksara, 2008), h, 144. Kitab kuning adalah nama yang yang diberikan untuk kitab-kitab klasik yang sebagian besar ditulis dalam bahasa Arab. Namun demikian, ada juga sebagian kitab kuning yang ditulis bukan dalam bahasa Arab, seperti bahasa Melayu, Jawa, Sunda, dan Madura, tetapi dengan aksara Arab-Melayu. Tulisan Arab-Melayu ini telah menjadi identita scultural dalam reproduksi intelektual Islam Melayu-Nusantara. Lihat Djohan Effendi, Pembaruan Tanpa Membongkar Tradisi: Wacana Keagamaan di Kalangan Generasi Muda NU Masa Kepemimpinan Dus Dur, (Jakarta: Penerbit Buku Kompas, 2010), h. 161; Ahmad Fawaid Sjadzili, "Islam Nusantara: Pertautan Doktrin dan Tradisi", Tashwirul Afkar, Edisi No. 26, Tahun 2008, h. 17.

${ }^{5}$ AzyumardiAzra, JaringanUlama Timur Tengah dan Kepulauan Nusantara Abad XVII dan XVIII, (Bandung: Mizan, 1994), h. 252; Azyumardi Azra dan Oman Fathurrahman, "Jaringan Ulama", dalamTaufik Abdullah et al. (ed.), Ensiklopedi Tematis Dunia Islam, (Jakarta: Ichtiar Baru Van Hoeve, 2005), jilid V, h.130; Abu Nazla Muhammad Muslim Safwan, 100 Tokoh Kalimantan, (Kandangan: Penerbit Sahabat, 2007), h. 2-3. 
was fulfilled by both parents6. In the palace environment, he was educated along with the sons of the Sultan to learn to study the Qur'an or some other branches of science ${ }^{7}$. Upon reaching adulthood, he was later married to a famous palace woman godly and devout woman named Bajut. When his wife was pregnant, the Sultan sent him to Haramain to study further at the cost of the Sultanate ${ }^{8}$. From the womb of his first wife was born a virtuous daughter named Syarifah binti Sheikh Muhammad Arsyad, who later became the mother of Fatima binti Sheikh Abdul WahabBugis9.

Fatima's father, Sheikh Abdul WahabBugis, also included a great and distinguished scholar. Abdul Wahab came from a quite noble family of nobles. He is a son of the king of Bugis land, South Sulawesi, which is titled Sadenreng Daeng BungaWardiyah ${ }^{10}$. So the full name of this character is Abdul WahabSadenrengDaengBungaWardiyah11. Like Sheikh Muhammad Arsyad, he also studied in the Middle East. Abdul Wahab spent much of his time studying in Egypt. Strongly suspected he studied for twenty years in Egypt, five years in Medina, and a few years in Makkah ${ }^{12}$. Together with Sheikh Abdul Rahman alMashri, Sheikh Abdul Shamad al-Palimbani, and Sheikh Muhammad Arsyad alBanjari, he is known as one of the leaders of the Jawi cleric ${ }^{13}$. The arrival of Sheikh Abdul Wahab himself to the land of Banjar accompanied the return of Sheikh Muhammad Arsyad14. He then assisted Sheikh Muhammad Arsyad, his

${ }^{6}$ Ahmad Basuni, Djiwajang Besar: M. Arsjad Bandjar Surgi Hadji Basar Kalampajan, (Kandangan: P.B. Musjawaratut thalibin, 1954), h. 6; H.A. Gazali Usmanet al., Sejarah Banjar, (Banjarmasin: Badan Penelitian dan Pengembangan Daerah Provinsi Kalimantan Selatan, 2003), h. 133; A. Hafizh Anshary, "Muhammad Arsyad al-Banjari", dalam Azyumardi Azraet al., (ed.), Ensiklopedi Islam, (Jakarta: Ichtiar Baru Van Hoeve, 2005), jilid I, h. 295; Muslich Shabir, Pemikiran Syekh Muhammad Arsyad al-Banjari tentang Zakat, (Bandung: Nuansa Aulia, 2005), h. 16; Zaenul Mahmudi dan Imam Safe'i, "Syekh Muhammad Arsyad al-Banjari", dalam Mastuki HS dan M. Ishom El-Saha (ed.), Intelektualisme Pesantren: Potret Tokoh dan Cakrawala Pemikiran di Era Pertumbuhan Pesantren, (Jakarta: Diva Pustaka, 2003), jilid I, h. 99; Muhammad Muslim Safwan, 100 Tokoh Kalimantan, h. 3.

7Muslich Shabir, Pemikiran Syekh Muhammad Arsyad al-Banjaritentang Zakat, (Bandung: Nuansa Aulia, 2005), h. 16.

8Zafry Zamzam, Syekh Muhammad Arsyad al-Banjary: Ulama Besar Juru Dakwah, (Banjarmasin: Penerbit Karya, 1979), h. 6; Abu Daudi, Maulana Syekh Muhammad Arsyad Al-Banjari, (Martapura: Yayasan Pendidikan Islam Dalam Pagar (Yapida), 2003), h. 44-45; M. Asywadie Syukur, Pemikiranpemikiran Syekh Muhammad Arsyad al-Banjaridalam Bidang Tauhid dan Tasawuf, (Banjarmasin: Comdes, 2009), h. v; Ahmad Basuni, Djiwajang Besar, h. 8; AzyumardiAzra, Jaringan Ulama, h. 252; Azyumardi Azra dan Oman Fathurrahman, "Jaringan Ulama”, h. 130; Muslich Shabir, Pemikiran Syekh Muhammad Arsyad, h. 17.

${ }^{9}$ Abu Daudi, Syekh Muhammad Arsyad, h. 46; ZafryZamzam, Syekh Muhammad Arsyad, h. 7, 13.

10Ahmad Basuni, Djiwajang Besar, h. 17; Abu Daudi, Syekh Muhammad Arsyad, h. 51; ZulfaJamalie dan Syaiful Hadi, "Mengungkap Riwayat dan Perjuangan Dakwah Syekh Abdul WahabBugis", Khazanah, Vol. IV, No. 01, Januari-Februari 2005, h. 4.

${ }^{11}$ Abu Daudi, Syekh Muhammad Arsyad, h. 49; Zulfa Jamalie dan Syaiful Hadi, "Mengungkap Riwayat", h. 4; A. Hafizh Anshary, "Muhammad Arsyad al-Banjari", h. 295.

12ZulfaJamalie dan Syaiful Hadi, "MengungkapRiwayat", h. 6.

${ }^{13} \mathrm{Abu}$ Daudi, Syekh Muhammad Arsyad, h. 51-55; Zulfa Jamalie dan Syaiful Hadi, "Mengungkap Riwayat", h. 6; A. Hafizh Anshary, "Muhammad Arsyad al-Banjari", h. 295.

14Zafry Zamzam, Syekh Muhammad Arsyad, h. 8; Abu Daudi, Syekh Muhammad Arsyad, h. 64; ZulfaJamalie dan Syaiful Hadi, "Mengungkap Riwayat", h. 4. 
father-in-law, in conducting community coaching and developing Islamic da'wah' ${ }^{15}$.

Fatima's mother, Sharifah binti Sheikh Muhammad Arsyad, was a virtuous and pious woman. Syarifah studied directly to his father, Sheikh Muhammad Arsyad16. He was even given his father's permission to teach religion for women17. Born in Martapura, Syarifah grew up without being accompanied by his beloved father. Upon hearing the news of his adult son, Sheikh Muhammad Arsyad then married him mujbir with Shaykh Abdul WahabBugis, his comrade studied at Haramain. However, when he arrived in Banjar it turned out that Syarifah had been married by the Sultan-as judge-with a man named 'Uthman and had given birth to a son named Muhammad As'ad. Muhammad Arsyad solves this case in a quite interesting way, by examining the time of marriage with his expertise in the field of astronomy given the time difference in Makkah and Martapura. From the results of the examination of marriage in Makkah occurred some time before the wedding in Martapura. Therefore, Syarifah's marriage bond with 'Uthman was canceled (difasakh), and the validity of marriage of Sharifah with Sheikh Abdul WahabBugis ${ }^{18}$.

From the marriage of Sheikh Abdul WahabBugis with Sharifahbinti Sheikh Muhammad Arsyad al-Banjari is born two children, namely Fatima and Muhammad Yasin ${ }^{19}$. Reportedly, Muhammad Yasin is not so old, so he has no zuriah (descent) and any biographical traces20. While Fatima reportedly married to Haji Muhammad Sa'idBugis, one of the relatives of Sheikh Abdul WahabBugis. From the marriage both produced two children, namely: Abdul Ghani and Halimah. Halimah is reported to have no offspring. While Abdul Ghani married Saudahbinti Mufti Muhammad As'ad, and gave birth to two children, but both died as a child. Abdul Ghani then remarried in MukahSerawak and got two children, namely: Muhammad Sa'id and Sa'diyah. Muhammad Sa'id is known to have two children, namely: Adnan and Jannah, while Sa'diyah gave birth to a child named Sailis in Sekadu Pontianak, West Kalimantan ${ }^{21}$.

Fatima binti Abdul Wahab many inherited the sciences of Islam from his father who is a great scholar and famous22. He was with his brother,

15Zafry Zamzam, Syekh Muhammad Arsyad, h. 9; Abu Daudi, Syekh Muhammad Arsyad, h. 90; Azyumardi Azra, Jaringa nUlama, h. 254; A. Hafizh Anshary, "Muhammad Arsyad al-Banjari”, h. 295; ZulfaJamalie dan Syaiful Hadi, "Mengungkap Riwayat", h. 8.

${ }^{16}$ Abu Daudi, Syekh Muhammad Arsyad, h. 73.

${ }^{17}$ Ahmad Basuni, Nur Islam di Kalimantan Selatan: SejarahMasuknya Islam di Kalimantan, (Surabaya: BinaIlmu, 1986), h. 43; Ahmad Basuni, Djiwajang Besar, h. 22.

18Marzuki Wahid dan Rumadi, Figh Madzhab Negara: Kritikatas Politik Hukum Islam di Indonesia, (Yogyakarta: LKiS, 2001), h. 122; ZafryZamzam, Syekh Muhammad Arsyad, h. 7-8;Abu Daudi, Syekh Muhammad Arsyad, h. 55-64.

19ZafryZamzam, Syekh Muhammad Arsyad, h. 15; Ahmad Basuni, Djiwajang Besar, h. 18; Abu Daudi, Syekh Muhammad Arsyad, h. 100; ZulfaJamalie dan SyaifulHadi, "Mengungkap Riwayat", h. 5 .

${ }^{20}$ Ahmad Basuni, DjiwajangBesar, h. 21.

21Syekh 'Abd al-Rahmân Shiddîq ibn Haji Muhammad 'Afîf Banjarî, Syajarat al-Arsyadiyyah, (Singapura: t.p., t.th.), h. 19; Abu Daudi, Syekh Muhammad Arsyad, h. 156; ZulfaJamalie dan Syaiful Hadi, “Mengungkap Riwayat”, h. 5; Alfisyah, "Geneologi Gerakan Perempuan Banjar”, Kandil, No. 11, Th. III, November-Januari, 2006, h. 8.

22ZulfaJamalie dan Syaiful Hadi, "Mengungkap Riwayat", h. 11; Saifuddin, "Peranan Fathimah binti Abdul Wahab Bugis dalam Sejarah Pendidikan Perempuan di Kalimantan", AlBanjari, vol. 8, no. 2, Juli 2009, h. 120. 
Muhammad As'ad, receiving education directly from his grandfather, Sheikh Muhammad Arsyad. The two grandchildren of Sheikh Arsyad studied a number of disciplines, including Arabic, Tafsir, Hadith, Usululuddin, and Jurisprudence23. After mastering various disciplinary branches, both were then allowed to teach religion. Muhammad As'ad became a teacher for men. Meanwhile, Fatima binti Abdul Wahab appeared as a teacher for women24. As a child born and raised in the middle of an educated family or even in a "pesantren" environment, Fatima gained greater access to engage in the transmission chains of Islamic scholarship and education. This kind of thing need not be surprising. Azra noted that the transmission of science for women is more informal, especially in the family. Here, the existence of fathers and mothers or other relatives has a very important role, at least providing religious knowledge above the average of the general public, or even become a cleric ${ }^{25}$.

Furthermore, the presence of Fatima was acknowledged as a pioneer for the emancipation of women in the field of education. He can also be said as KartiniBanjar even if judging from the history of his existence he has been present and pioneered education for women long before R.A. Kartini (1879-1904) was born. If Kartini in Java comes with the mission of equality of education for women, Fatima has precisely pioneered the teaching for women ${ }^{26}$. Furthermore, if Kartini's struggle is known through his letters27, Fatima's involvement in Islamic scholarship and scholarship tradition is known through her Malay Parukunan.

Perhaps many readers do not realize that the book of Malay Parukunan was written by a woman named Fatima binti Abdul Wahab, because she was later printed on behalf of a male cleric, her own uncle (Mufti Jamâluddîn)28, known as the JamâluddînParukunan. The book is simple-parukunan means a basic description of the pillars of Islam and the pillars of faith-but is one of the most popular among similar books29. Jamâluddîn was an influential man, the most prominent scholar of South Kalimantan in his day. He is the son of Shaykh Muhammad Arsyâd, from his marriage to a Chinese descendant named Go HwatNio (Guwat).30

Based on the above it is not surprising that among scholars and researchers emerged different opinions about the true identity of the author of the book ParukunanMelayu. Some scholars argue that the book was written by Mufti

${ }^{23}$ Abd al-Rahmmân Shiddîq, Syajarat al-Arsyadiyyah, h. 7, 19; Abu Daudi, Syekh Muhammad Arsyad, h. 74, 156; Ahmad Basuni, DjiwajangBesar, h. 22; Alfisyah, "Geneologi Gerakan”, h. 8.

$24^{`}$ Abd al-RahmânShiddîq, Syajarat al-Arsyadiyyah, h. 7; Abu Daudi, Syekh Muhammad Arsyad, h. 156; Ahmad Basuni, DjiwajangBesar, h. 22.

${ }^{25}$ Azyumardi Azra, “Ulama Perempuan”, h. 92-93.

${ }^{26}$ Alfisyah, “Geneologi Gerakan", h. 6; Saifuddin, "Peranan Fathimah”, h. 124.

${ }^{27}$ Surat-surat R.A. Kartini tersebut telah diedit dan diterbitkan dengan judul Habis Gelap Tebitlah Terang, (Jakarta: P.N. Balai Pustaka, 1972).

${ }^{28}$ Martin van Bruinessen, Kitab Kuning, Pesantren, danTarekat: Tradisi-tradisi Islam di Indonesia, (Bandung: Mizan, 1995), h. 177. Di halaman pertama kitab itu tertulis "karangan bagi al-'alim al'allâmah Mufti Jamâluddînibn al-marhûmal-'âlim al-fâdhil al-Syaikh Muhammad Arsyâd al-Banjari". LihatJamâluddinibn al-Marhûm al-'Âlim al-Fâdhil al-Syaikh Muhammad Arsyâd al-Banjari, Parukunan, (Singapura, Jedah: al-Haramain, t.th.), h. 1.

${ }^{29}$ Martin van Bruinessen, KitabKuning, h. 177.

30`Abd al-RahmânShiddîq, Syajarat al-Arsyadiyyah, h. 28; Muhammad Muslim Safwan, 100 Tokoh Kalimantan, h. 60-61; Muslich Shabir, PemikiranSyekh Muhammad Arsyad, h. 19. 
Jamâluddin ${ }^{31}$. This opinion is perhaps the most popular because in some print editions clearly written the name Mufti Jamâluddîn. Some scholars, such as Ahmad Basuni, mention that the same book was written by Sharifahbinti Sheikh Muhammad Arsyad ${ }^{32}$.

So far it is not known exactly why Mufti Jamâluddîn is in the name of the book. In the world of yellow books there is no copyright, and copying someone else's writing without credit has become a habit. However, according to Martin van Bruinessen's observations, it may be that the identity of the author is actually deliberately concealed-in keeping with the established presumption that making up a book is a male occupation33. Similarly, Ahmad Basuni gives the reason why the book is on behalf of Mufti Jamâluddîn that it is not appropriate at the time to mention the name of the woman as the author of the book. ${ }^{34}$

\section{Thought in the Field of Jurisprudence}

Fatima's thought in the field of jurisprudence follows the al-Shafii school of thought as mentioned at the end of his work "wahuwa kitâb fifigh al-Shâfi' $\imath^{\prime \prime} 35$. The discussion of jurisprudence in this book is much broader than that of monotheism. In the sermon section of the book is generally mentioned about the five pillars of Islam ${ }^{36}$. Of the five pillars of Islam, the prayer material that gets the most extensive portion of the discussion, then fasting, and shahadah is only slightly mentioned in the introduction. While the zakat and pilgrimage are only mentioned as elements of the pillars of Islam and not explained at all. Beyond that, the discussion of fiqhmuamalah, munakahah and jinayah, also not found here, because the discussion is more directed to the material worship, especially prayer. So that at the end of the book is also mentioned as "Prayer Parade". ${ }^{37}$

The discussion of jurisprudence begins with the law of water; Followed by unclean and how to eliminate them; The law of defecation and his wife; An obligatory bathing, bath fardu, sunna, and makruhnya; The condition of taking water of prayer, sunna, and makruhnya; Requirements of prayer; Ordinances of worship, rukunnya, and sunna; A who abrogates the prayers and the makruhnya; Sunnah prayer; Praying qasar and plural. Also described about the requirements of the law of fasting; Mandatory requirements for Ramadan fasting; One that requires breaking the fast; All sunna fasting; Jimak in the month of Ramadan; And the fasting of the sunna.

\section{C.1.Discussion on Water, Unclean, Wudu, and Bath}

According to the book of ParukunanMelayu, water is divided into four parts, namely: water muthlaq; Water makrûh; Water musta'mal; Andmutanajjis water. Water muthlaq, consists of seven parts: rainwater; Dew; frozen water; sea water; River water; well water; And water lake. The muthlaq water can change its smell, taste, and color for three reasons: first, it changes because mukhalathah

\footnotetext{
31Muhammad Muslim Safwan, 100 Tokoh Kalimantan, h. 65.

${ }^{32}$ Ahmad Basuni, Djiwajang Besar, h. 22-23.

33Martin van Bruinessen, Kitab Kuning,h. 177.

${ }^{34}$ Ahmad Basuni, Djiwajang Besar, h. 23.

35Lihat Jamâluddîn, Parukunan, h. 39.

36LihatJamâluddîn, Parukunan, h. 2.

37Jamâluddîn, Parukunan, h. 39.
} 
means mixing with other indistinct objects that can not be distinguished and separated from water like kamkama (turmeric) and lime; Second, it changes because mujâwir means mixed with other sacred objects that can be distinguished and separated from water such as gaharu wood and sandalwood; And third, it changes because of the rauh that is the smell of carcass mingled with water. Water makruh, consists of three types: very hot water; Very cold water; And the water is sunning in a very hot country. Mustakmal water, which is water that has been used to eliminate small or large or used hadas for bathing the corpse. The mutanajjis water, that is, water that is less than qullah enters unclean in it, whether it changes its taste, its smell, its color, or not. ${ }^{38}$

Meanwhile, unclean is divided into three parts: unclean mughaladlah, that is dog and pig and something that comes from one of them; Unclean mukhaffafah, ie the urinating of boys who have not yet eaten food other than milk; And unclean mutawassithah, the unclean outside of the two unclean species mentioned, such as dung, pus, blood, vomit, madhi, wadi, and wine. ${ }^{39}$

Requirement to take water prayer (wudu) there are seven things: Islam; Mumayyiz; Holy of haidh and childbirth; The sacredness of a which prevents the coming of water to the limbs that must be washed; Knowing all his fard; Do not mengiktikadkan the fardu in taking the water of prayer as a sunna; And with holy water and sanctify. For the one who always confronts plus one more condition, ie in time. While the pillars of wudu are: intention; Washing face; Put both hands to both elbows; Sweep a little from the scalp or a hair on the head or half; Washing both feet to the ankles; and orderly. ${ }^{40}$

Then the things that require bathing are five things: to die for the Muslims; Haidh; Childbirth; Wiladah; and janabat. While things that become harmonious or fardunya bath there are two: the intention with the heart; and flatten the water all over the limbs. ${ }^{41}$

\section{C.2. Discussion on Prayer}

The legitimate requirement of praying there are six things: knowing will enter the time with confidence or zhan; Facing the Qibla; Closing aurat; Holy of the great and small; Holy from unclean; And know all fardu and sunahnya. While the pillars of prayer are: intention; Takbiratul ihram; stand up; Reading fatihah; Bowing; Iktidal and stop in it; Prostrate and stop in it; Sitting between two prostrations and stopping inside; Prostrate second and stop in it; Tahiyyat end; Reading shalawat; regards; And orderly. Then the things that break the prayer are eleven: speechless, though only one letter understood its meaning; Do many deeds in succession (outside the prayer movement); eat and drink; Working on the rukunqaulî or rukunfi'lî as well as doubtful of the validity of intention; Intending to decide a prayer; Menta'liqkan decide to pray something; The coming of the hadas before the first selalam greetings; an unforgivable odious miscarriage thereof; Open aurat; Turning the chest away from the Qibla; and apostasy in worship. 42

\footnotetext{
38Jamâluddîn, Parukunan, h. 5-6.

39Jamâluddîn, Parukunan, h. 7.

40Jamâluddîn, Parukunan, h. 10.

41Jamâluddîn, Parukunan, h. 8-9.

42Jamâluddîn, Parukunan, h. 11-16.
} 


\section{C.3. Discussion on Fasting}

Terms of law (meaning rukun) fasting there are seven, namely: intention with the heart; Refrain from jimak; Refrain from intentional vomiting; Refrain from inserting anything into the open body cavity inward; Islam in those fasting days; Holy of haidh and childbirth; Intelligent. While the requirements of fasting Ramadan is: Islam; Balig; and intelligent. The things that require breaking the fast are: sick; Fear of perishing or perishing in a person; and traveler. Furthermore, the sunna fasting quite a lot, among them: hasten breaking the fast; Feeding the fasting man; pre-dawn meal; Abandoning all the required desires that do not break the fast; Leaving bloody, tasting food, and kissing his wife in his mouth or other.43

At least by looking at the systematic discussion, this work of Fatima seems to be closer to the works of the Shafi'i jurisprudence. Discussion of worship material in Shafi'iyah jurisprudence usually follows the following systematic: Kitâb al-Thahârah, Kitâb al-Shalâh, Kitâb al-Zakâh, Kitâb al-Shiyâm, Kitâb alI'tikâf, and Kitâb al-Hajj ${ }^{44}$. Although not addressing the whole topic, the composition of religious jurisprudence in this book includes: al-thahârah, alshalâh, and al-shiyâm. In addition, in the books of Jurisprudence Shafi'iyah religious material explanations often use a technical framework, such as the requirement of prayer, prayer, pillars, legal requirements tayamum, and so on ${ }^{45}$. This is also clearly reflected in Fatima's work. Furthermore, the main reference book of Fatima's work also follows the Syafi'i school of thought, for example Nihâyat al-Muhtâj by al-Ramli (d.1004 H).

\section{Conclusion}

From the exposure in advance it is clear that Fatima binti Abdul Wahab is a female cleric who contributed to the thinking in the Malay Islamic intellectual tradition. In his intellectual development, he studied direct Sheikh Muhammad Arsyad in various fields of Arabic-religious science, exegesis, hadith, ushuluddin, jurisprudence-and after mastering the sciences he became a teacher for women. Fatima's role in the transmission and tradition of Malay Islamic scholarship is not only known through his position as teacher for women but also through his work, ParukunanMelayu, which is widely studied in almost all Malay-Nusantara territories.The book of Malay Parukunan generally outlines the pillars of faith (tauhid) and the pillars of Islam (jurisprudence). Thoughts in the field of monotheism clearly follow Aswaja's notions, especially Ash'arites, which include: believing in God; Believe in his angels; Believe in his books; Believe in his messengers; Believe in the Last Day; Believe in the good and bad of Allah. In the field of jurisprudence follows the Shafi'i school whose material includes: water law; unclean and how to eliminate them; The law of defecation and his wife; an obligatory bathing, bath fardu, sunna, and makruhnya; The condition of taking water of prayer, sunna, and makruhnya; Requirements of prayer; ordinances of worship; a man who abrogates the prayers and the makruhnya; Sunnah prayer; Qasar and plural worship; The requirements of the law of fasting;

43Jamâluddîn, Parukunan, h. 17-18.

44Muslich Shabir, Pemikiran Syekh Muhammad Arsyad, h. 25.

45 Abdul Djamil, Perlawanan Kiai Desa, h. 53-54. 
Mandatory requirements for Ramadan fasting; One that requires breaking the fast; fasting sunna; Jimak in the month of Ramadan; Fasting sunna; and others.

\section{Bibliography}

Abdullah, H.W. Muhd. Saghir. Syeikh Muhd.Arsyad al-Banjari: Matahari Islam. Mempawah: Pondok Fathonah, 1982.

Alfisyah. "Geneologi Gerakan Perempuan Banjar". Kandil, No. 11, Th. III, November-Januari, 2006.

Amin, Ahmad. Fajr al-Islam. Beirut: Dar al-Kutub al-'Ilmiyyah, 1425 H/2004 M.

Anshary, A. Hafizh. "Muhammad Arsyad al-Banjari", dalamAzyumardiAzraet al., (ed.). Ensiklopedi Islam. Jakarta: IchtiarBaru Van Hoeve, 2005.

Asyari, Suaidi. Nalar Politik NU dan Muhammadiyah: Over Crossing Java Sentris. Terj. Mohamad Rapik. Yogyakarta: LKiS, 2010.

Azra, Azyumardi. Historiografi Islam Kontemporer: Wacana, Aktualitas, dan Aktor Sejarah. Jakarta: Gramedia Pustaka Utama, 2002.

"Ulama Perempuan dan Wacana Islam", dalam Reposisi Hubungan Agama dan Negara: Merajut Kerukunan Antar umat. Jakarta: Penerbit Buku Kompas, 2002.

. "Biografi Sosial-intelektual Ulama Perempuan: Pemberdayaan Historiografi", dalam Jajat Burhanudin (ed.). Ulama Perempuan Indonesia. Jakarta: Gramedia Pustaka Utama, 2002.

. Jaringan UlamaTimur Tengah dan Kepulauan Nusantara Abad XVII dan XVIII. Bandung: Mizan, 1994).

dan Oman Fathurrahman. "Jaringan Ulama", dalam Taufik Abdullah et al. (ed.). Ensiklopedi Tematis Dunia Islam. Jakarta: Ichtiar Baru Van Hoeve, 2005.

al-Banjari, Jamâluddin ibn al-Marhûm al-'Âlim al-Fâdhil al-Syaikh Muhammad Arsyâd. Parukunan. Singapura, Jedah: al-Haramain, t.th.

Banjarî, Syekh 'Abd al-Rahmân Shiddîq ibn ㅂaji Muhammad 'Afîf. Syajarat alArsyadiyyah. Singapura: t.p., t.th.

Basuni, Ahmad. Djiwajang Besar: M. Arsjad Bandjar Surgi Hadji Basar Kalampajan. Kandangan: P.B. Musjawaratutthalibin, 1954. - Nur Islam di Kalimantan Selatan: Sejarah Masuknya Islam di Kalimantan. Surabaya: BinaIlmu, 1986.

Van Bruinessen, Martin. Kitab Kuning, Pesantren, danTarekat: Tradisi-tradisi Islam di Indonesia. Bandung: Mizan, 1995.

Daud, Alfani. Islam dan Masyarakat Banjar: Deskripsi dan Analisa Kebudayaan Banjar. Jakarta: Raja GrafindoPersada, 1997.

Daudi, Abu. Maulana Syekh Muhammad Arsyad Al-Banjari. Martapura: Yayasan Pendidikan Islam DalamPagar (Yapida), 2003.

Djamil, Abdul. Perlawanan Kiai Desa: Pemikirandan Gerakan Islam KH. Ahmad Rifa'i Kalisalak. Yogyakarta: LKiS, 2001.

Effendi, Djohan. Pembaruan Tanpa Membongkar Tradisi: Wacana Keagamaan di Kalangan Generasi Muda NU Masa Kepemimpinan Dus Dur. Jakarta: PenerbitBukuKompas, 2010.

Ibn Yahyâ, 'Utsmân ibn 'Abdillâhibn 'Aqîl. Sifat DuaPuluh. Surabaya: Maktabat Muhammad ibn Ahmad Nabhânwa Aulâduh, t.th. 
Jamalie, Zulfadan Syaiful Hadi."Mengungkap Riwayatdan Perjuangan Dakwah Syekh Abdul Wahab Bugis".Khazanah, Vol. IV, No. 01, Januari-Februari 2005.

Juhaidi, Ahmad. "Untuk Kartini di Tanah Banjar". Http://ahmadjuhaidi.blogspot.com/2009/05/untuk-kartini-di-tanah-banjar-html, diakses tanggal 21 Juli 2010.

Mahmudi, Zaenuldan Imam Safe'i. "Syekh Muhammad Arsyad al-Banjari", dalam Mastuki HS dan M. Ishom El-Saha (ed.). Intelektualisme Pesantren: Potret Tokoh dan Cakrawala Pemikiran di Era Pertumbuhan Pesantren. Jakarta: Diva Pustaka, 2003.

Nawawi, Ramli (ed.). Sejarah Pendidikan Daerah Kalimantan Selatan. Banjarmasin: Departemen Pendidikan dan Kebudayaan, 1992/1993.

al-Ramlî, Syams al-Dîn Muhammad ibnAbi al-'Abbâs Ahmad ibn Hamzah ibn Syihâb al-Dîn. Nihâyat al-Muhtâjilâ Syarh al-Minhâj. Beirut: Dâr al-Kutub al'Ilmiyyah, 1424 H/2003 M.

Safwan, Abu Nazla Muhammad Muslim. 100 Tokoh Kalimantan.Kandangan: PenerbitSahabat, 2007.

Saifuddin, Norlaila, dan Halimatus Sakdiah. "Ulama Perempuan Banjar dalam Penulisan Kitab Kuning: Studi Historisdan Tekstual atas Kitab Parukunan Melayu". Banjarmasin: Pusat Penelitian IAIN Antasari, 2008.

Shabir, Muslich. Pemikiran Syekh Muhammad Arsyad al-Banjari tentang Zakat. Bandung: Nuansa Aulia, 2005.

Siradj, Said Agiel. Ahlussunnahwal Jama'ah dalam LintasSejarah. Yogyakarta: LKPSM, 1997.

Sjadzili, Ahmad Fawaid. "Islam Nusantara: Pertautan Doktrin dan Tradisi". TashwirulAfkar, Edisi No. 26, Tahun 2008.

al-Syahrastânî, Abû al-Fath Muhammad ibn 'Abd al-Karîm. al-Milalwa al-Nihal. Beirut: Dâr al-Kutub al-'Ilmiyyah, t.th.

Syukur, M. Asywadie. Pemikiran-pemikiran Syekh Muhammad Arsyad al-Banjari dalam Bidang Tauhid dan Tasawuf. Banjarmasin: Comdes, 2009.

Usman, H.A. Gazalietal. Sejarah Banjar. Banjarmasin: Badan Penelitian dan Pengembangan Daerah Provinsi Kalimantan Selatan, 2003.

Zamzam, Zafry. Syekh Muhammad Arsyad al-Banjary: Ulama Besar Juru Dakwah. Banjarmasin: PenerbitKarya, 1979.

Zuhairini etal. Sejarah Pendidikan Islam. Jakarta: Bumi Aksara, 2008. 